\title{
TINGKAT KEPUASAN KONSUMEN TERHADAP KUALITAS LAYANAN PADA WASERDA YAPONPES DAYAMA DESA JEROWARU KABUPATEN LOMBOK TIMUR
}

\author{
Muhammad Nashruddin \\ Prodi Agribisnis - Universitas Gunung Rinjani \\ Email: nashugr@gmail.com
}

\begin{abstract}
The study aims to determine the level of customer satisfaction with service quality Waserda Ponpes Dayama Jerowaru Village. The method used in this research is the method of Important Performance Analisys (IPA) with the presentation of data descriptively. The number of samples taken as many as 30 respondents taken by random sampling. Based on the calculation results obtained 936 customer satisfaction score score that means consumers feel quite satisfied. Based on the analysis using Performance Analisys (IPA) method, it is known that some important attributes that have been stated have contributed to give satisfaction to the consumer that is attribute number 1 (wide parking area) and number 10 (strategic location)
\end{abstract}

Keywords: Consumer satisfaction, service quality, attributes

\section{Pendahuluan}

Menjamurnya keberadaan toko modern yang merambah sampai keperkampungan menyebabkan keberadaan toko kecil atau warung kelontong menjadi terancam. Fasilitas toko modern yang serba memadai dengan jenis barang yang ditawarkan lebih lengkap dan beragam bila dibandingkan dengan toko kelontong telah menjadi pemicu bergesernya preferensi masyarakat dalam menentukan tempat berbelanja. Terlebih lagi jarak yang berdekatan antara warung kelontong/toko usaha kecil dengan toko modern menyebabkan munculnya persaingan yang tidak seimbang. Melita Iffah dkk. menyebutkan bahwa jarak antara toko usaha kecil dan lokasi minimarket yang berada dalam satu jangkauan pelayanan akan sangat berpengaruh pada preferensi masyarakat dalam menentukan tempat berbelanja. Jika lokasi toko usaha 
kecil dan lokasi minimarket berada dalam satu lingkup pelayanan, maka besar kemungkinan masyarakat akan berbelanja di minimarket. Kehadiran minimarket telah menuntut toko usaha kecil untuk dapat meningkatkan pelayanan dan membenahi fasilitas pada tokonya untuk memberikan pelayanan terbaik kepada konsumennya. Hal ini memungkinkan terdapatnya perubahan pada preferensi masyarakat, untuk lebih memilih berbelanja di minimarket daripada berbelanja di toko kecil. ${ }^{1}$

Beralihnya konsumen merupakan konsekwensi logis dari suatu pilihan terhadap hasrat pemenuhan akan kebutuhannya, karena konsumen sebagai individu atau kelompok dengan dasar pertimbangan tertentu memutuskan untuk membelanjakan uangnya pada suatu jenis barang atau jasa tertentu dalam tempo waktu tertentu selalu dengan tujuan untuk mencapai kepuasan maksimal. Konsumen dalam berbelanja akan selalu memiliki preferensi yang kuat di dalam mengambil keputusan untuk menentukan lokasi atau tempat berbelanja, apa dan berapa yang harus dikonsumsi. Hal ini tidak terlepas dari atribut-atribut pelayanan yang diberikan oleh suatu toko atau tempat berbelanja.

Menurut Philip Kotler 2002 yang dikutip Anindita 2012 terdapat 4 faktor utama yang dapat mempengaruhi konsumen dan perilaku pembeliannya yaitu :

\section{Cultural Factors (Faktor Budaya)}

Faktor budaya merupakan faktor utama yang memberikan pengaruh yang sangat besar terhadap prilaku konsumen peranan yang diperankan oleh konsumen dalam mengambil keputusan untuk melakukan pembelian sangat ditentukan oleh :

a. Culture (budaya)

Dimana budaya adalah suatu hal sangat mendasar yang dapat mempengaruhi keinginan dan prilaku seseorang dalam hal ini budaya dan kebiasaan yang ada dalam lingkup suatu negara akan persepsi seseorang terhadap suatu hal, serta prilaku yang terbentuk dalam diri seseorang yang berangkat dari institusi yang terkecil, yaitu keluarga. b. Subculture (sub budaya)

1 Melita Iffah, Fauzul Rizal Sutikno, Nindya Sari, "Pengarub Toko Modern Terhadap Toko Usaba Kecil Skala Lingkungan (Studi Kasus: Minimarket Kecamatan Blimbing, Kota Malang) (Jurnal Tata Kota dan Daerah Volume 3, Nomor 1, 2011), 55-556 tatakota.ub.ac.id/index.php/tatakota/ article/viewFile/129/128. 
Setiap budaya yang ada disetiap negara atau wilayah tertentu, terdapat sub-sub budaya lebih spesifik yang pada kahirnya dapat mencerminkan prilaku sosial dan identitas masing-masing anggotanya. Sub budaya meliputi kewarganegaraan, agama, suku, etnis serta letak geografis.

c. Sosial Class (kelas atau tingkatan sosial)

Mencerminkan kedudukan atau tindakan dimana seseorang dipandang atau memandang orang lain seseuai dengan keberadaan dalm suatu Komunitas masyarakat tertentu. Yang biasanya dapat dibedakan dari tingkat pendapatan seseorang, latar belakang pendidikan, berbicara dan banyak karekteristik yang lainnya.

2. Sosial Factors (faktor sosial)

a. Reference Groups (kelompok referensi)

Yaitu suatu kelompok yang terdiri dari orang-orang yang memiliki pengaruh secara langsung maupun tidak langsung terhadap sikap perilaku seseorang.

b. Family (keluarga)

Dalam hal ini keluarga yang meliputi orang tua, suami, istri, anak adalah intitusi yang paling kuat mempengaruhi seseorang dalam hal melakukan keputusan pembelian terhadap suatu kelompok atau jasa.

\section{Personal Factors (faktor pribadi)}

Keputusan yang diambil oleh konsumen untuk melakukan pembelian juga dipengaruhi oleh kerakteristik pribadi masing-masing individu, seperti tingkat usia dan tingkatan dalam keluarga, pekerjaan, situasi ekonomi, gaya hidup derta kepribadian dan cara pandang seseorang terhadap diri sendiri.

\section{Phsycological Factors (faktor psikologis)}

Perilaku pembeli sebelum menentukan pilihan pada produk atau jasa yang akan dibelinya, dipengaruhi oleh 4 (empat) faktor psikologis yang paling utama yaitu motivasi, 
persepsi, pemahaman terhadap suatu hal, serta faktor kepercayaan dan sikap terhadap suatu hal. ${ }^{2}$

Selain keempat faktor tersbut yang tidak kalah pentingnya dalam memberikan pengaruh terhadap preferensi konsumen dalam menentukan tempat berbelanja adalah adanya kualitas layanan. Kualitas layanan akan menjadi salah satu preferensi yang akan mendorong konsumen untuk berbelanja disuatu toko retail. Bagi pengusaha yang mampu memberikan kualitas pelayanan yang prima maka tentunya loyalitas konsumen untuk beli kembali pada toko tersebut akan dapat dipertahankan. Namun sebaliknya jika pengusaha tidak mampu memberikan kualitas pelayanan yang baik maka minat konsumen untuk melakukan beli kembali di toko tersebut akan sulit untuk dipertahankan.

Dalam ISO 8402 dan SNI (Standar Nasional Indonesia), dijelaskan pengertian kualitas adalah keseluruhan ciri dan karakteristik produk atau jasa yang kemampuannya dapat memuaskan kebutuhan, baik yang dinyatakan secara tegas maupun tersamar. Istilah kebutuhan diartikan sebagai spesifikasi yang tercantum dalam kontrak maupun kriteriakriteria yang harus didefinisikan terlebih dahulu. ${ }^{3}$

Jika kualitas layanan dapat dijaga oleh toko ritel maka akan dapat memunculkan kepuasan pada pelanggan. Untuk itulah merupakan suatu kewajiban bagi pengelola toko ritel untuk berusaha memuaskan konsumen dari segi layanannya. Engel, et al (1990) yang dikutip oleh Tjiptono (2008: 24) menyatakan bahwa kepuasan konsumen merupakan evaluasi purna beli dimana alternatif yang dipilih sekurang-kurangnya sama atau melampaui harapan konsumen ${ }^{4}$. Sedangkan Kottler dan Keller (2009 : 138) memberikan definisi kepuasan yakni bahwa kepuasan (satisfaction) adalah perasaan senang atau kecewa seseorang yang timbul karena membandingkan kinerja yang dipersepsikan produk (atau hasil) terhadap ekspektasi mereka. Jika kinerja gagal

\footnotetext{
${ }^{2}$ Bernadetta Dwiyani Anindita, "Analisis Kepuasan Pelanggan Pada Alfamart Tembalang Dari Dimensi Pelayanan (Studi Kasus Pada Alfamart Jl. Ngesrep Timur V / 69, Kota Semarang) (Semarang: Skripsi Ekonomika dan Bisnis Universitas Diponegoro, 2012), 19-21.

${ }^{3}$ http://www.pengertianpakar.com/2015/05/pengertian-kualitas-menurut-pakar.html

${ }^{4}$ Fandy Tjiptono, Strategi Pemasaran. (Jakarta : Andy Offset, 2008), 24.
} 
memenuhi ekspektasi maka konsumen tidak puas, sebaliknya jika memenuhi ekspektasi maka konsumen akan puas ${ }^{5}$.

Memilih tempat berbelanja adalah proses interaksi antara strategi pemasaran peritel dan karakteristik individual dan situasional dari pembeli. Karakteristik individual seperti gaya hidup menyebabkan pandangan umum tentang aktivitas yang terlibat dalam perilaku pembelian suatu produk. Para peritel mempengaruhi aktivitas ini dengan strategi iklan dan promosi. Karakteristik pembeli juga mempengaruhi citra tempat berbelanja. Citra tempat berbelanja pada gilirannya mempengaruhi pilihan tempat berbelanja dan produk akhir atau pembelian merek. Jika pengalaman masa lalu memuaskan, maka pilihan akan bersifat kebiasaan. Kecuali jika faktor-faktor lain berubah sejak kunjungan terakhir. Proses pemilihan tempat berbelanja tertentu merupakan fungsi dari karakteristik konsumen dan karakteristik tempat berbelanja. Dengan kata lain, tiap pangsa pasar konsumen akan memiliki suatu citra dari berbagai tempat berbelanja. Konsumen memilah-milah atau membanding-bandingkan karakteristik tempat berbelanja yang dirasakan dengan kriteria evaluasi dari konsumen inti ${ }^{6}$.

Perilaku konsumen meliputi prilaku yang dapat diamati seperti jumlah yang dibelanjakan, kapan, dengan siapa, oleh siapa, dan bagaimana barang yang sudah dibeli tersebut dapat dikonsumsi. Juga termasuk variabel-variabel yang tidak dapat diamati seperti nilai-nilai yang dimiliki kosumen, kebutuhan pribadi, persepi, bagaimana mereka mengevaluasi alternatif, dan apa yang mereka rasakan tentang kepemilikan dan penggunaan produk yang bermacam-macam. Prilaku konsumen juga menyangkut suatu proses keputusan sebelum pembelian serta tindakan dalam memperoleh, memakai, mengkonsumsi, dan menghabiskan produk ${ }^{7}$.

\footnotetext{
${ }^{5}$ Philip Kotler dan Kevin Lane keller, Manajemen Pemasaran. Edisi ke-13. (Jakarta : Erlangga, 2009), 138.

${ }^{6}$ Hendrikus Arinanda," Analisis Variabel Pembentuk. Kepuasan Konsumen Pada Ritel Minimarket Alfamart dan Indomaret Di Wilayah Pesanggrahan Jakarta Selatan. (Jakarta: Jurusan Manajemen Fakultas Ekonomi, Universitas Gunadarma), 2-3.

${ }^{7}$ Bernadetta Dwiyani Anindita, "Analisis Kepuasan Pelanggan Pada Alfamart Tembalang Dari Dimensi Pelayanan (Studi Kasus Pada Alfamart Jl. Ngesrep Timur V / 69, Kota Semarang) (Semarang: Skripsi Ekonomika dan Bisnis Universitas Diponegoro, 2012), 18-19.
}

65. Palapa: Jurnal Studi Keislaman dan Ilmu Pendidikan 
Keberadaan toko modern yang saat ini telah menyasar disetiap kecamatan di Kabupaten Lombok Timur termasuk Kecamatan Jerowaru telah mempengaruhi perilaku beli masyarakat terhadap warung serba ada dan warung kelontong lainnya yang ada di tempat tersebut. Termasuk juga pengaruhnya terhadap warung serba ada (waserda) Yaponpes Dayama yang selama ini menjadi rujukan berbelanja sebagian masyarakat di wilayah Kecamatan Jerowaru, baik dalam bentuk eceran maupun grosiran. Waserda merupakan salah satu jenis usaha ritel yang telah lama berkembang ditengah-tengah masyarakat. Waserda merupakan warung kelontong yang menjual berbagai jenis produk yang dibutuhkan konsumen untuk memenuhi kebutuhan sehari-hari. Kata "serba ada" bukan berarti mutlak semua produk ada dijual pada warung serba ada, namun kata "serba ada" hanya merupakan prase yang menunjukkan adanya berbagai jenis produk yang dijual pada tempat tersebut yang jumlah produk tersebut jauh lebih beranekaragam bila dibandingkan dengan warung kelontong lain pada umumnya.

Keberadaan pasar modern seperti Indomaret dan Alfamart yang telah menyasar masuk ke kampung-kampung saat ini merupakan sebuah ancaman serius bagi warungwarung kelontong yang dikelola oleh masyarakat. Dari sisi jenis produk dan jasa layanan yang ditawarkan sudah tentu keberadaan pasar modern akan menggerus konsumen warung-warung kelontong tersebut karena warung modern tersebut memiliki produk dan kualitas layanan yang lebih baik. Ditengah persaingan yang sangat ketat seperti itu maka tentunya Waserda (warung serba ada) sebagai salah satu jenis usaha retail yang digerakkan oleh masyarakat harus mampu memperbaiki citra ditengah konsumennya sehingga konsumennya memiliki retensi dan loyalitas yang tinggi untuk tetap berlelanja pada warung serba ada.

Dengan kondisi menjamurnya pasar modern yang menyasar kampung-kampung inilah yang melatar belakangi penulis tertarik untuk meneliti terkait tingkat kepuasan konsumen terhadap kualitas layanan pada waserda dengan mengambil lokasi pada Waserda Yaponpes Dayama Desa Jerowaru, sehingga diharapkan nantinya dengan adanya hasil penelitian ini akan ada upaya pembenahan yang dilakukan pada waserda Dayama Jerowaru sebagai salah satu upaya untuk memperbaiki kualitas layanan. 


\section{Rumusan Masalah}

Berdasarkan latar belakang tersebut di atas maka dapat dirumuskan masalah dalam penelitian ini adalah bagaimanakah tingkat kepuasan konsumen terhadap layanan pada Waserda Yaponpes Dayama Jerowaru?

\section{Tujuan Penelitian}

Tujuan dari penelitian ini adalah untuk mengetahui tingkat kepuasan konsumen terhadap kualitas layanan pada Waserda Yaponpes Dayama Jerowaru.

\section{Manfaat Penelitian}

Penelitian ini diharapkan dapat sebagai bahan masukan bagi pengelola waserda Yaponpes Dayama dalam melakukan perbaikan kinerja pada atribut-atribut yang dianggap penting tetapi berkinerja rendah dalam memberikan kepuasan kepada konsumen.

\section{Metodelogi Penelitian}

Penelitian ini dilaksanakan di Waserda Yaponpes Dayama Desa Jerowaru Kecamatan Jerowaru Kabupaten Lombok Timur. Penentuan Waserda Yaponpes Dayama sebagai lokasi penelitian dengan pertimbangan bahwa Waserda Yaponpes Dayama merupakan waserda pertama di Kecamatan Jerowaru. Penentuan responden sebanyak 30 responden dilakukan secara random sampling terhadap pengunjung Waserda Yaponpes Dayama Jerowaru. Data dalam penelitian ini berupa data primer dan data sekunder. Data primer diperoleh melalui kuesioner dan wawancara lansung dengan pengunjung waserda, sedangkan data sekunder di peroleh dari dokumen yang ada pada pengelola waserda. Variabel yang diukur dalam penelitian ini adalah tingkat kepuasan konsumen terhadap pelaksanaan atribut pelayanan Waserda Yaponpes Dayama Desa Jerowaru yang terdiri dari 11 atribut yang telah melalui uji validitas dan releabilitas. 
Penyajian data dilakukan secara deskriptif dengan metode Importance and Performance Analysis (IP A).

\section{Hasil Dan Pembahasan}

Dari hasil pengolahan data dapat diketahui bahwa karakteristik responden pada penelitian ini yakni jenis kelamin pria sebanyak 13 orang (43\%), perempuan 17 orang (57\%) dengan rentang usia 18-25 tahun sebanyak 7 orang (23\%), 18-25 tahun sebanyak 8 orang (27\%), 26-35 tahun sebanyak 9 orang (30\%), 36-55 tahun sebanyak 4 orang $(13 \%)$ dan lebih dari 55 tahun sebanyak 2 orang (7\%). Data tingkat pendidikan yakni T'TSD-TSD 11 orang (37\%), SLTP-SMU 12 orang (40\%), Perguruan tinggi 7 orang $(23 \%)$.

Berdasarkan data pekerjaan diketahui karakteristik responden yakni sebanyak 12 orang $(40 \%)$ responden berprofesi sebagai petani, sebanyak 2 orang (7\%) sebagai PNS, sebanyak 1 orang (3\%) sebagai TNI/Polri, dan sebanyak 15 orang berwiraswasta. Berdasarkan data tingkat pendapatan diketahui bahwa sebanyak sebanyak 15 orang $(50 \%)$ berpenghasilan antara $<1$ juta-1 juta rupiah, sebanyak 11 orang $(37 \%)$ berpenghasilan antara 2-3 juta, sebanyak 3 orang (10\%) berpenghasilan 4-5 juta, dan sebanyak 1 orang (3\%) berpenghasilan lebih dari 5 juta rupiah.

Dalam penelitian ini ada 11 atribut layanan dan pelaksanaan terhadap atribut layanan tersebut oleh Waserda Yadama yang menjadi aspek kajian peneliti. Adapun kesebelas atribut layanan tersebut dan tingkat pelaksanaannya adalah sebagai berikut:

\section{Area parkir yang luas}

Dari lampiran 2 terlihat bahwa sebanyak 30 orang responden (100\%) mengatakan bahwa keberadaan areal parkir yang luas masuk kategori sangat penting. Dari segi skor kriteria kepentingan diperoleh nilai skor masimal yakni 150. Sedangkan dalam aspek pelaksanaan atribut sebanyak $8(27 \%)$ responden menganggap pelaksanaan penyediaan areal parkir yang luas pada Waserda Yaponpes Dayama masuk kategori cukup memuaskan, sebanyak 9 orang $(30 \%)$ responden mengaggap bahwa luas areal parkir yang dimiliki Waserda Yaponpes Dayama cukup memuaskan bagi pelanggan, dan sebanyak 13 orang (43\%) responden menganggap bahwa keberadaan areal parkir 
Waserda Yaponpes Ponpes Dayama sangat memuaskan. Lahan parkir adalah tempat pemberhentian kendaraan dalam jangka waktu pendek atau lama, sesuai dengan kebutuhan pengendara.

\section{Keanekaragaman produk yang dijual}

Berdasarkan data yang diperoleh diketahui bahwa sebanyak 8 orang (27\%) responden menganggap bahwa atribut keanekaragaman produk yang dijual penting, dan sebanyak 22 orang (73\%) menganggap atribut keanekaragaman produk yang dijual sebagai atribut yang sangat penting. Sedangkan dari aspek pelaksanaan atribut penting tersebut diketahui bahwa sebanyak 15 orang (50\%) responden menganggap bahwa pelaksanaan atribut keanekaragaman produk yang dijual tidak memuaskan, sebanyak 6 orang $(20 \%)$ responden menganggap pelaksanaan atribut keanekaragaman produk yang dijual kurang memuaskan, dan sebanyak 9 orang (30\%) responden menganggap bahwa pelaksanaan atribut keanekaragaman produk yang dijual masuk kategori cukup memuaskan.

\section{Gerai waserda yang luas dan nyaman}

Dari lampiran 2 dapat diketahui bahwa 30 orang atau 100\% responden menganggap bahwa atribut gerai waserda yang luas dan nyaman masuk kategori sangat penting. Sedangkan dari aspek pelaksanaan atribut diketahui bahwa 24 orang (80\%) responden menganggap bahwa pelaksanaan atribut Gerai waserda yang luas dan nyaman tidak memuaskan, 1 orang $(3 \%)$ responden menganggap pelaksanaan atribut gerai waserda yang luas dan nyaman kurang memuaskan dan 5 orang (17\%) responden menganggap pelaksanaan atribut gerai waserda yang luas dan nyaman cukup memuaskan. Dari hasil observasi memang terlihat bahwa kondisi gerai Waserda Ponpes Dayama memang tidak terlalu luas sehingga membuat pengunjung kurang nyaman dalam gerak lalu lalang.

\section{Bahasa yang mudah dimengerti dari karyawan}

Dari data pada lampiran 2 diketahui bahwa sebanyak 2 orang (7\%) responden menganggap bahwa atribut bahasa yang mudah dimengerti dari karyawan tidak penting, sebanyak 4 orang (13\%) menganggap bahwa atribut bahasa yang mudah dimengerti dari

69. Palapa: Jurnal Studi Keislaman dan Ilmu Pendidikan 
karyawan kurang penting, 4 orang (13\%) menganggap bahwa atribut bahasa yang mudah dimengerti dari karyawan cukup penting, 8 orang (27\%) responden menganggap atribut bahasa yang mudah dimengerti dari karyawan penting, dan sebanyak 12 orang (40\%) menganggap bahwa atribut bahasa yang mudah dimengerti dari karyawan masuk kategori sangat penting,

Pada kriteria pelaksanaan atribut sebanyak 20 orang (67\%) responden merasa tidak puas terhadap pelaksanaan atribut bahasa yang mudah dimengerti dari karyawan, sebanyak 6 orang (20\%) responden menganggap kurang memuaskan, dan sebanyak 4 orang $(13 \%)$ responden menganggap pelaksanaan atribut bahasa yang mudah dimengerti dari karyawan cukup memuaskan. Dari hasil observasi peneliti terlihat bahwa memang dalam keseharian karyawan Waserda Yaponpes Dayama kurang memperhatikan penggunaan bahasa yang komunikatif.

\section{Jam layanan tepat waktu}

Tingkat kepentingan atribut Jam layanan tepat waktu menurut 1 orang (3\%) responden dianggap kurang penting, sebanyak 5 orang (17\%) menganggap cukup penting, 9 orang (30\%) menganggap penting, dan sebanyak 15 orang (50\%) responden menganggap Jam layanan tepat waktu masuk kategori Sangat penting.

Dalam pelaksanaan atribut penting diketahui bahwa sebanyak 7 orang (23\%) responden menganggap bahwa pelaksanaan atribut Jam layanan tepat waktu cukup memuaskan, sebanyak 8 orang (27\%) menganggap memuaskan, dan sebanyak 15 orang (50\%) menganggap pelaksanaan atribut Jam layanan tepat waktu sangat memuaskan. Berdasarkan hasil observasi terlihat bahwa jam kerja pada Waserda Yaponpes Dayama cukup tepat waktu, walaupun kadang pada saat tertentu misal karena ada kematian pada warga masyarakat Desa Jerowaru jam layanan pada Waserda Yaponpes Daya kadang telat dibuka atau ditutup lebih cepat, termasuk juga pada waktu-waktu jam shalat.

\section{Gerai waserda yang bersih}

Sebanyak 6 orang responden (20\%) menganggap atribut Gerai waserda yang bersih cukup penting, sebanyak 10 orang (33\%) responden menganggap penting, dan 
sebanyak 14 orang (47\%) responden menganggap atribut Gerai waserda yang bersih sebagai atribut yang sangat penting.

Pada kriteria pelaksanaan atribut Gerai waserda yang bersih sebanyak 8 orang $(27 \%)$ responden menganggap tidak memuaskan, 10 orang $(33 \%)$ menganggap kurang memuaskan, dan sebanyak 12 orang (40\%) menganggap cukup memuaskan. Secara umum terlihat kondisi gerai Waserda Yaponpes Dayama memang kelihatan cukup bersih.

\section{Rasa aman dalam berbelanja}

Sebanyak 2 orang responden (7\%) mengatak bahwa atribut Rasa aman dalam berbelanja kurang penting, 7 orang (23\%) mengatakan cukup penting, 5 orang $(17 \%)$ mengatakan penting dan 16 orang (53\%) mengatakan atribut Rasa aman dalam berbelanja masuk kategori sangat penting

Pada kriteria pelaksanaan atribut sebanyak 2 orang (7\%) mengatakan pelaksanaan atribut Rasa aman dalam berbelanja cukup memuaskan, 6 orang (20\%) responden menganggap memuaskan, dan 22 orang (73\%) menganggap atribut Rasa aman dalam berbelanja dalam pelaksanaanya sangat memuaskan.

\section{Memberikan pelayanan tanpa perbedaan}

Sebanyak 7 orang (23\%) responden menganggap atribut Memberikan pelayanan tanpa perbedaan cukup penting, 8 orang (27\%) menganggap penting, dan sebanyak 15 orang $(50 \%)$ responden menganggap atribut Memberikan pelayanan tanpa perbedaan sangat penting.

Penilaian responden berdasarkan tingkat pelaksanaan atribut Memberikan pelayanan tanpa perbedaan pada Waserda Yaponpes Dayama Jerowaru 1 orang (3\%) mengatakan memuaskan, 9 orang (30\%) mengatakn kurang memuaskan, 11 orang (37\%) mengatakan cukup memuaskan, 4 orang (17\%) mengatakan memuaskan dan 4 orang $(13 \%)$ mengatakan sangat memuaskan.

\section{Adanya layanan pengantaran barang}

Sebanyak 4 orang $(13 \%)$ responden mengatakan atribut Adanya layanan pengantaran barang masuk kategori cukup penting, sebanyak 9 orang (30\%) mengatakan

71. Palapa: Jurnal Studi Keislaman dan Ilmu Pendidikan 
penting, dan sebanyak 17 orang (57\%) responden menganggap atribut Adanya layanan pengantaran barang sangat penting.

Sebanyak 3 orang $(10 \%)$ responden menganggap bahwa pelaksanaan atribut Adanya layanan pengantaran barang pada Waserda Ponpes Dayama tidak memuaskan, 3 orang $(10 \%)$ responden menganggap kurang memuaskan, 7 orang $(23 \%)$ responden menganggap cukup memuaskan, 7 orang $(23 \%)$ responden menganggap memuaskan, dan 10 orang (33\%) responden menganggap pelaksanaan atribut Adanya layanan pengantaran barang sangat memuaskan. Dari hasil observasi diketahui bahwa Waserda Yaponpes Dayama memiliki 3 armada untuk mengangkut barang pesanan pelanggan yakni 1 unit motor kaisar, 1 unit mobil bak terbuka, dan 1 unit mobil truk tertutup.

\section{Lokasi yang strategis}

Sebanyak 2 orang $(7 \%)$ responden menganggap atribut Lokasi yang strategis cukup penting, 12 orang (40\%) responden menganggap penting, dan 16 orang (53\%) responden menganggap sangat penting. Dari aspek pelaksanaan atribut diketahui bahwa sebanyak 9 orang $(30 \%)$ responden menganggap kurang memuaskan, 8 orang menganggap cukup memuaskan, 3 orang (10\%) menganggap memuaskan, dan sebanyak 10 orang $(33 \%)$ responden menganggap pelaksanaan atribut lokasi yang strategis masuk kategori sangat memuaskan. Jika dilihat dari lokasi keberadaan Waserda Yaponpes Dayama yang berada dipinggir jalan dapat dikatakan bahwa Waserda Yaponpes Dayama berada pada posisi yang startegis, namun karena berada pada lahan milik umum hal ini menjadi kendala tersendiri bagi keberlanjutan Waserda Yaponpes Dayama.

\section{Penyediaan toilet}

Sebanyak 2 orang $(7 \%)$ responden menganggap atribut Penyediaan toilet cukup penting, 8 orang $(27 \%)$ responden mengatakan atribut Penyediaan toilet penting, dan 20 orang $(67 \%)$ responden menganggap atribut Penyediaan toilet sangat penting.

Dalam pelaksanaannya sebanyak 25 orang (83\%) responden menganggap bahwa pelayanan berupa Penyediaan toilet tidak memuaskan, 4 orang (13\%) responden menganggap kurang memuaskan, dan 1 orang (3\%) responden menganggap cukup memuaskan. Dari hasil observasi terlihat pelayanan berupa fasilitas toilet belum ada pada 
Waserda Yaponpes Dayama sehingga pelanggan hanya memanfaatkan fasilitas toilet masjid Jami’ Jerowaru yang kebetulan berdekatan posisinya dengan Waserda Yaponpes Dayama.

Untuk menentukan tingkat kepuasan konsumen terhadap pelaksanaan atribut pelayanan secara keseluruhan pada Wasrda Yaponpes Dayama digunakan rumus sebagai berikut:

Skor maksimum $=\sum$ item pertanyaan $\mathrm{x}$ Sskor tertinggi yang bisa diberikan $\mathrm{x}$ ¿responden

Skor minimum $=\sum$ item pertanyaan $\mathrm{x}$ Sskor terendah yang bisa diberikan $\mathrm{x}$ $\sum$ responden

Interval skor $\quad=\underline{\text { skor maksimum-skor minimum }}$

\section{Kategori}

Skor maksimum $=11 \times 5 \times 30=1650$

Skor minimum $=11 \times 1 \times 30=330$

Interval skor $=1650-330 / 5=264$

Sehingga didapatkan nilai interval tingkat kepuasan konsumen terhadap pelaksanaan atribut pelayanan secara keseluruhan pada Waserda Yaponpes Dayama adalah sebagai berikut:

$$
\begin{array}{lll}
330-594 & =\text { Tidak memuaskan } \\
594-858 & =\text { Kurang memuaskan } \\
858-1122 & =\text { Cukup memuaskan } \\
1122-1386 & =\text { Memuaskan } \\
1386-1650 & =\text { Sangat memuaskan }
\end{array}
$$

Karena skor kumulatif 936 point, menunjukkan bahwa tingkat kepuasan konsumen terhadap pelaksanaan atribut kepentingan pada Waserda Dayama Desa Jerowaru Cukup memuaskan yakni berada pada rentang nilai 858-1122. 


\section{Important Performance Analisys (IPA)}

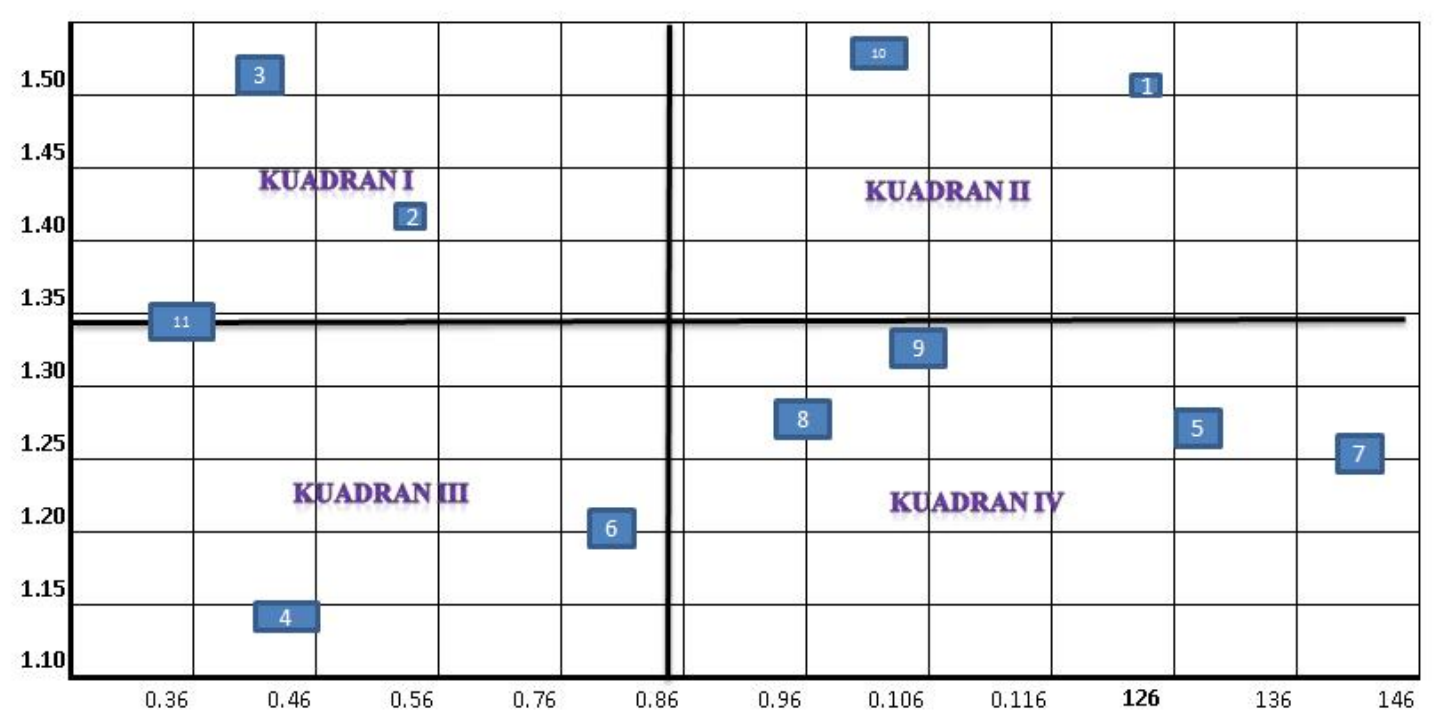

\section{Kuadran I}

Pada kuadaran ini ditunjukan elemen atau atribut yang dianggap penting oleh konsumen tetapi kurang mendapat perhatian dari pihak pengelola Waserda Yaponpes Dayama, sehingga tingkat kinerja (Performance) di bawah rata-rata dan kurang memuaskan pengunjung. Pihak pengelola Waserda Dayama harus lebih memperhatikan untuk meningkatkan kinerja pada atribut nomor 2 (Gerai yang bersih dan nyaman), atribut nomor 3 (Gerai waserda yang luas) dan atribut nomor 11 (Penyediaan toilet).

\section{Kuadran II}

Pada kuadran ini menunjukan atribut pelayanan yang dianggap oleh pengunjung berkinerja baik dan telah mampu memberikan rasa puas pada pelanggan. Kinerja Waserda Yaponpes Dayama di atas rata-rata, sehingga pengunjung menjadi puas. Selanjutnya pihat Waserda Yaponpes Dayama harus menjaga kinerja yang sudah ada agar tetap baik. Adapun atribut pelayanan yang termasuk kuadran II ini adalah atribut nomor 1(Area parkir yang luas) dan nomor 10 (Lokasi yang strategis). 


\section{Kuadran III}

Kuadran III menunjukan atribut pelayanan yang kurang penting oleh pengunjung dan juga kurang perhatian oleh pihak Waserda Yaponpes Dayama sehingga pengelolaannya secara wajar saja karena memiliki prioritas yang rendah untuk ditingkatkan. Adapapun yang masuk pada atribut pada kuadran III ini adalah atribut nomor 4 (Bahasa yang mudah dimengerti dari karyawan), atribut nomor 6 (Gerai waserda yang bersih).

\section{Kuadran 4}

Pada kuadran ini menunjukan atribut pelayanan yang dianggap kurang penting oleh pengunjung, akan tetapi dilaksanakan sangat baik oleh Waserda Yaponpes Dayama Jerowaru yang mungkin sangat berlebihan. Dalam atribut ini sebaiknya pihak Waserda Yaponpes Dayama Jerowaru mengurangi porsi perhatian dan curahan energy untuk, serta mengalokasikan energi untuk memperbaiki kinerja pada atribut pelayanan yang dianggap sangat penting oleh pengunjung tetapi kurang mendapat perhatian dari pihak pengelola Waserda Yaponpes Dayama Jerowaru. Adapun atribut pelayanan yang termasuk dalam kuadran ini adalah atribut nomor 5 (Jam layanan tepat), 7 (Rasa aman dalam berbelanja), 8 (Memberikan pelayanan tanpa perbedaan), 9 (Adanya layanan pengantaran barang).

\section{Catatan Akhir}

Skor penilaian tingkat kepuasan konsumen Waserda Yaponpes Dayama Desa Jerowaru adalah 936 point, yang berarati bahwa tingkat kepuasan konsumen terhadap pelayanan Waserda Yaponpes Dayama Desa Jerowaru masuk kategori Cukup Memuaskan. Atribut yang dianggap pelayanannya memuaskan konsumen adalah atribut nomor 1(area parkir yang luas) dan nomor 10 (lokasi yang strategis). Untuk meningkatkan kepuasan konsumen maka Beberapa atribut penting yang harus menjadi perhatian bagi pengelola Waserda Yaponpes Dayama adalah atribut nomor 2 (gerai yang bersih dan nyaman), atribut nomor 3 (gerai waserda yang luas) dan atribut nomor 11 (penyediaan toilet).

75. Palapa: Jurnal Studi Keislaman dan Ilmu Pendidikan 
Muhammad Nashruddin

\section{Daftar Rujukan}

Anonimous, 2015. Pengertian Kualitas Menurut Pakar. http: // www. pengertianpakar.com

Anindita, Bernadetta Dwiyani. 2012. Analisis Kepuasan Pelanggan Pada Alfamart Tembalang Dari Dimensi Pelayanan (Studi Kasus Pada Alfamart Jl. Ngesrep Timur V / 69, Kota Semarang) Skripsi. Ekonomika dan Bisnis Universitas Diponegoro. http:/ / eprints.undip.ac.id. Diunduh 7 Maret

Arinanda, Hendrikus 2009. Analisis Variabel Pembentuk Kepuasan Konsumen Pada Ritel Minimarket Alfamart dan Indomaret Di Wilayah Pesanggrahan Jakarta Selatan. Jurusan Manajemen Fakultas Ekonomi, Universitas Gunadarma. Jakarta. http:/ /gunadarma.ac.id. Diunduh 7 Maret 2017

Kotler, Philip dan Kevin Lane Keller, 2009. Manajemen Pemasaran. Edisi ke-13. Erlangga, Jakarta.

Iffah, Melita et.al 2011. Pengarub Toko Modern Terbadap Toko Usaha Kecil Skala Lingkungan (Studi Kasus: Minimarket Kecamatan Blimbing, Kota Malang) (Jurnal Tata Kota dan Daerah Volume 3, Nomor 1, 2011) hlm. 55-556 http:/ / tatakota.ub.ac.id/index.php. Diunduh 12 Maret 2017

Tjiptono, Fandy. 2008. Strategi Pemasaran. Andy Offset, Jakarta. 